\title{
d-lysergic acid diethylamide
}

He awoke to blue. It touched everything, coloring it the way it does when you've slept in the middle of the day. Everything seemed hazy as he sat up in the car, pulling the lever with his left hand, the seat propelling him forward, head aching and eyes burning from dehydration. The landscape around the car was deserted, just fields and grass, and the thought that this may have been a mistake crashes into his head like it had several times already since he'd left the city. He heard a faint sound in his ears, a music, Sirens calling out to him from the rearview mirror, which he adjusted a bit and looked at the reflection of the road behind him. The road leading back to...

Back to what?

The same shit he'd been through already? Just thinking about it gave him that familiar feeling beneath his ribs that started to work its way up, just touching his brainstem with misery.

No. Fuck that.

Shaking his head, John sighed and leaned back, fishing around the right side of his waist for his cell phone. Finding it, he unsnapped the carrying case and looked at it.

2:50P

John found himself sighing again and then looking outside at the sunlight; it was later summer but still summer, and he knew he had at least another hour of daylight. Blinking the weariness from his eyes, he reached over to the floor of the passenger side and grabbed the almost empty bottle of water and took a drink. As he brought his head back down, he felt a light pop in his neck, and an intensely pleasant sensation dropped down and up his spine like someone threading silk through the cord of nerves running up the center of his vertebrae. He closed his eyes and savored the feeling, then opened them and saw something moving just beyond his field of vision. He snapped his head to the right and squinted at the edge of the field, the grass as high as his window there, and he felt eyes staring back at him. He didn't see anything now, but he knew he did just a second beforehand, just inside his peripheral vision, a shadow.

Did it have arms and legs, or was it an animal?

He remembered that he'd dropped a tab just before he'd left, chalked it up to that, and hit the power locks to make sure the doors were secure, just in case. He had to piss, but he didn't dare do it outside now; he'd stop up ahead somewhere and do it, a few miles away. He slid the key deeper into the ignition, having left it out just enough so it wouldn't cause that irritating dinging noise, and turned it. 'The engine turned over with a satisfying ease, and John found himself forgetting what he saw in the excitement of movement.

John was laying on the ground; the grass felt like a swimming pool, so cool that it made the sensation of pressure disappear, his nerves sensing the ground as if it were a liquid, and the sky was spread out above him in blue and white pastels. His eyes unfocused, clouds splitting in his vision, and he 
relaxed his muscles. He thought he could feel the earth moving beneath him, the sky above him moving as well, and the rotations made bile rise into his throat. The jolt in his stomach came suddenly, and he was forced into a fetal position, hot fluid leaving his mouth, the regurgitation so strong his vision distorted even further, and the darkness of unconsciousness threatened to overcome him. He closed his eyes, forced himself to focus on the burning in his throat and mouth, the chunks of mostly-digested food clinging to the cracks in his teeth. He sucked spit into the center of his mouth, tasting the combination of sour bile and bitter stomach acid. He sat up, opened his eyes and turned away from where he had vomited. He spat then repeated the procedure several times until the film in his mouth grew more tolerable.

"Jesus Christ, hope I brought a damn toothbrush." He glanced down the hill towards the small town, his car parked in the parking lot of a back-water gas station. Wiping his mouth, he got up and began to walk down the hill, every step making his stomach flip.

The mirror in the bathroom of the gas station was just as filthy as the toilet, and the sink was stained with the grease that had been washed off into it. John sighed and dampened a sandpaper towel, then began to scrub the mirror enough that he could see his own face. He washed the sink as best he could before finally running the water until it got lukewarm, knowing it would never get hot, splashed water on his face and rinsed out his mouth. He had forgotten his toothbrush in his rush to leave. Why would he have remembered something so mundane?

He looked at himself in the mirror and squinted at his reflection.

The reflection's mouth moved. "What the fuck are you doing?"

"Getting away."

"Away from what?" There was something in the reflection's eyes, an anger.

"You know what." His reply felt concrete; he knew he was talking to himself.

"Okay, then where?" Some strange split formed, a kind of duality. It didn't feel like him anymore, it felt like some sort of separate entity.

I don't know. He didn't see the mouth move in the mirror as he responded to its question.

"C'mon, John, where you going to run to?" Now the mouth moved and the face judged him, he could see it in the eyes, it was just waiting for an excuse to lash out.

I don't know, dammit! Though sure his reply was angry, it didn't echo in the bathroom; it didn't seem to enter the world at all.

"Sure you do, you know where you're running."

What do you want me to say? That I'm running to Benjamin? That I'm hoping if anyone will help me, my brother will?

"Why would your brother help you after you left him to bury Mom alone?"

Those eyes, that hatred, he never liked mirrors, especially not when he was tripping. He distrusted what they showed him. In some ways, he had grown to distrust himself. In almost the same way, he grew to distrust beauty because he correlated it with idiocy or indecency. The causal relationship may not have actually been there, but the connection had been made any- 
ways so that when a pretty girl showed an interest in him, she was either a slut or a moron. He kept from looking at the mirror as he made his way out of the bathroom. The cashier said something that sounded like, "Are you okay?" but the tone made him think she was really saying, "You look like shit," and he wasn't about to respond to that tone. He bought some pre-packaged crackers with cheese and green tea, distrusting his stomach to handle a soda or candy, and ignored the cashier's question. He paid and left.

\section{5-methoxy-N,N-dimethyltryptamine}

He was running, and he knew it.

The roads stretched behind him, fractured images splayed on his mind like a film projecting onto a shredded screen. Dreams, memories, hallucinations -the further back he tried to remember the harder it was to get a handle on what had actually happened.

From what he could remember, it went like this:

A room, broken window, mattress on the floor, gray covered everything like ashes from cigarettes, there was smoke in the air like vapor from a boiling pot of water, but it clung to everything, smelling like sunshine and gasoline, car exhaust mixing with the smell of steamed broccoli, and he could sense something was wrong. She looked pale, skinny, bags under her eyes, like a zombie except not the living dead kind of zombie, but the juju-voodoo kind that you read about before the movies, the kind that has been created by a conscious act of mankind, those horrible bags under her eyes, the hollows in her cheeks, her meth mouth. She was speedballing, easing off the coke because of the black tar, and she looked at him, those eyes shining in the dim light cast through the cracks in the busted window. We're just different people; he knew she was speaking out of a needle-hole, drained and distorted the way she'd become. The words hurt but echoed his thoughts so perfectly that he realized exactly what she had become and he shook his head. The movement seemed sluggish, and he just looked at her with a newfound contempt for what she'd become. Standing on shaky legs, looking down at her as she sat splayed on the dirty mattress, her legs parting beneath that Salvation Army skirt of hers, and though he thought briefly of how long it had been since he'd actually ventured down to that part of her anatomy, he quickly guessed that had he actually seen what was left down there, he would probably have nightmares for decades. Apparently, there was at least one benefit to having Crystal cock, his flaccid penis saving him from his nightmarish responsibility as her lover. He walked out, delirious, and wondered if she would come down and try to find him, until he remembered that she hadn't come down off the junk in almost a year now.

He glanced at his cell phone again; whether to truly look at the time or to see if he had somehow magically missed the vibration of a phone call, he didn't know. Either way, it helped him stop thinking about the catalyst for his leaving.

He took a deep breath and got out of the car. 
It was amazing how these little towns were so perfectly spaced from one another that it seemed while you were driving to take an eternity to get to one, but then, when you arrived, you couldn't believe how little time had actually passed. He walked in and ignored the cashier, going straight for the bathroom. This time the sink was a bit cleaner, the mirror recently scrubbed, but the toilet was just as dirty as the last one. He urinated, washed his hands, left the bathroom, and got a cup of coffee, his stomach now feeling better.

"Din't I just see you here?"

His eyebrows knit together slightly, and he tilted his head just a bit to the left and said, "I don't think so. I stopped at a place a lot like this at the last town."

"No, you was just in here." Her country drawl made the skin on his back crawl beneath the cold sweat that gravity was starting to pull down his spine. He shrugged, paid for his coffee, and ignored her continued mumbling as he walked away.

John got in the car, this time starting it up, taking a drink of the coffee, and then carefully backing out and taking off. Driving made things better, even if physically he felt like a lump of dogshit left to turn rigid and white in some lonely corner of a public park. The wound Alice had made was so fine that when he positioned his emotions a certain way, it came together like two smooth edges of a slice in his flesh. It may still have been there, but the pain of exposing the soft flesh of the inside was gone, and it appeared to be healed, or at least scabbed over, at first glance. The illusion of being okay.

It's not okay, and deep down, beneath the layers of denial and selfprotection, he knew everything was not okay. He knew that the second the context of his emotional state changed, the second he stopped too long, the wound would reopen, bleed, and he would be exposed once again to the truth of what lay in the direction of the exhaust pipe.

The scenery whipped by as he stepped on the gas pedal; he flipped the radio on to a dead-air station and turned it up: static crackling, the whirring sounds of rotating noise like someone putting a live microphone to a grindstone in some forgotten basement and letting it spill out into the airwaves like so much noise pollution. So he turned it up louder, anything to block the tears, anything to keep from breaking down, anything to help him forget, and he was so lost in trying to forget that he didn't know how long it took him to notice the flashing light in his rear-view mirror.

He never did hear the siren, so loud was the screeching static and grindstone-on-microphone noise of the radio as he pulled over, not turning it down until after he pulled over, and then trying hard not to let his upper body appear to be moving towards it. He knew that kind of crap was what got people shot, that attempting to appear as if you weren't doing anything illicit made you typically appear to actually be doing something illicit, enough that you either got shot or searched.

He watched the cop take his plate number and run it, then get out of the cruiser. It was a woman cop; he could tell by the parenthetical shape of her hips. He rolled down the window and watched her in his driver's side mirror as she unsnapped the strap of the holster, resting her hand on the grip.

"Do you know why I pulled you over?" 
"No," do you? He hoped the unspoken words didn't show on his face.

"I pulled you over because you were speeding; license, registration, and proof of insurance please?"

"I have to reach for the glove-box - "He let the sentence trail off so she could respond to his non-verbal question. Her nod told him to go ahead and reach, so he reached slowly, opened it, and pulled out the little brown folder that held his registration and insurance information. Then he handed it to her and took his wallet from his pocket, fished out his license, and handed that over. He looked up and out at his reflection in her mirrored sunglasses, the world painted in a colorful display, appearing to swim within the lenses like eels, his own head a lamprey, ready to snap out of the glasses and latch onto the first warm thing from which it could get blood.

He turned his gaze away from those Salvador Dalí sunglasses and looked straight ahead, resting his hands in plain sight on the steering wheel. He glanced into the rearview mirror then jerked his head back to stare into it, forehead making wrinkles over the space between and above his eyebrows. He squinted, not sure if he was really seeing what he thought he was seeing, but when the faded mannequin that he was seeing didn't go away, he twisted around to look out through the back of his car.

"Something wrong?"

Her voice cut through his stupor, a straight razor through paper; he blinked again, rubbed his eyes, and looked back at her before responding.

"No, I'm alright, just road fatigue."

"That right? You stopped at all since you left your hometown?"

"Once for a couple hours, laid in the grass, think I took a nap."

"Well, I know you city-boys like to think you're tough enough to go a couple days without sleep, but out here that's as dangerous as driving under the influence." She saw the puzzled look on his face, so continued, "It's the scenery, or what you might call the lack of. Seeing what looks like the same shit over and over again can make someone who's wide awake nod off, let alone someone who's tired. So, where you headin'?"

Where am I heading? "Actually, I'm going to Burlington to see my brother."

"You've got a ways to go, then. You might want to stop and get some rest before you continue."

"Oh, there a place nearby I can stop?"

"Not for another twenty miles. I suggest going back the ten miles to Cambrin. Get yourself a room and sleep until you're rested."

"That the name of the last town?" He couldn't help but think of what he saw in the rearview mirror and shudder a bit, though apparently it wasn't violent enough for her to notice.

"Yeah, look I'm only going to give you a warning on this, but remember that you're not in the city anymore, there aren't a thousand people doing the same traffic violations as you out here."

He nodded but found his gaze drawn to her lips. He'd seen a mugshot of Richard Speck once from when he was caught, and her smile made him think of that picture. Obviously she didn't have the crags and huge nose that Speck did, but somehow the smile was the same, something behind it.

"Thank you," he said, feeling that somehow she needed closure in order 
to walk away.

"You're welcome. Now find yourself someplace to get some sleep. I don't care if it's the side of the road, long as you don't end up wrapping yourself around a tree." At that she walked away, leaving him to look intently back in the mirror, but the image that swam there before was gone now.

He watched her leave in the mirror, and when she got into her car, he put his into drive and began pulling away. A short time later, he found a gravellined space to pull over onto and take a nap.

His dreams twisted around him, memories warped into surrealist imagery that would make Escher proud. Alice was acid-etched into every image like a watermark. Fluid dripped from the purulent haloes tracked all over her arms. The bags under her eyes yawned like two black holes waiting for him to fall into them. It wasn't until she said that they were different people that he was able to see what they'd become. He wanted to save her but knew that quitting was one of those things that must be done alone.

\section{3,4,5-trimethoxy-ß-phenethylamine}

He pulled into the parking lot in Burlington at 3:45pm and got out of the car. The stretch made a couple of his vertebrae pop, and colors shot from the outside of his peripheral vision across the field, to die spectacular Starry Night deaths on either side of his nose. He took a deep breath and exhaled slowly, letting himself enjoy the sudden flashback of euphoria that had attached itself to him. When it passed, he looked up at the sign; it was a trademark travel name, this 24 hour restaurant, not quite fast food, but certainly no sit-down and relax diner, either. He felt the stirring inside his gut like snakes waiting to sink their fangs into his heart and inject the poison of doubt. 